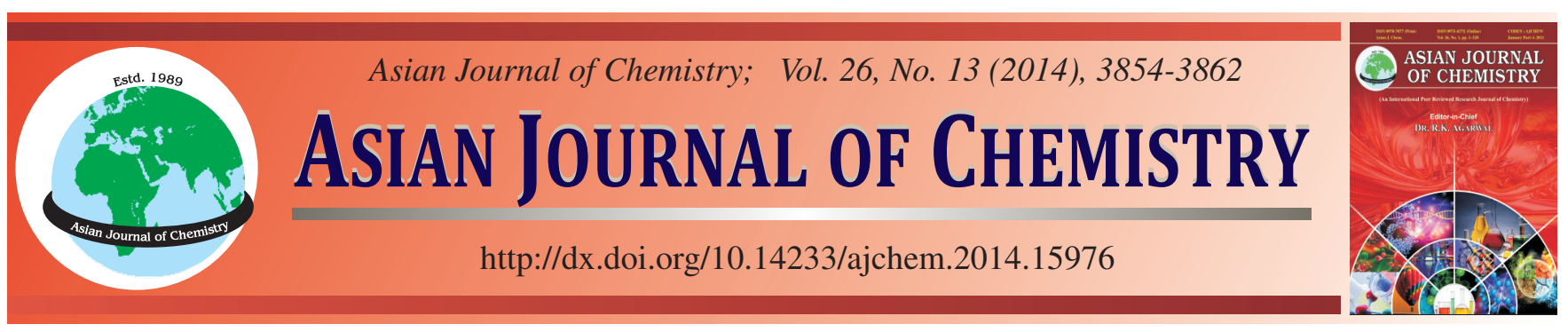

\title{
Synthesis of Spectral, Thermal and Electrochemical Properties of New Thermally Stable: Blue Light Emitting Materials Based Aromatic Polyamide
}

\author{
Azhar Kamil Rashid ${ }^{*}$, Rosiyah Binti Yahya and Phang Sook Wai
}

Department of Chemistry, Faculty of Science, University of Malaya, 50603 Kuala Lumpur, Malaysia. University of Baghdad, Baghdad, Iraq

*Corresponding author: Fax:+79674193; Tel: +60104259265; E-mail: azhar_almasody@yahoo.co.uk

\begin{abstract}
A three new triphenylamine-containing aromatic diacid monomers, 4,4'-dicarboxy-4"-phenoxy-triphenylamine (Ma), 4,4'-dicarboxy-4"(N-pyrrolyl)triphenylamine (Mb), 4,4',4",4"'-(1,4-phenylenebis(azanetriyl))tetrabenzoic acid (Mc) were successfully synthesized via the aromatic nucleophilic flouro-displacement reaction of 4-fluorobenzonitrile with aniline-derivatives, respectively using sodium hydride as the base, followed by alkaline hydrolysis of the dinitrile intermediate (Ia),(Ib), (Ic). A series of poly(amine-amide)s were prepared by the direct phosphorylation polycondensation from the newly synthesized diacid monomer with various aromatic diamines. FTIR, ${ }^{1} \mathrm{H}$ and ${ }^{13} \mathrm{C}$ NMR spectroscopic techniques were used to identify the chemical structures of the intermediate dicyano, carboxylic acid monomer and resultant poly(amine-amide)s. These aromatic poly(amine-amide)s were found to be easily soluble in a variety of organic solvents and could afford strong and hard films via solution casting. They exhibited excellent thermal stability associated with high glass transition temperatures $\left(\mathrm{T}_{\mathrm{g}}=246.28-292.62{ }^{\circ} \mathrm{C}\right)$ and $10 \%$ weight loss temperatures in excess of $578{ }^{\circ} \mathrm{C}$ in nitrogen. In dilute NMP solution, these polymers exhibited a medium to strong photoluminescence in the blue region at 423-488 $\mathrm{nm}$. Cyclic voltammetry of the poly(amineamide)s films cast onto an indium tin oxide-coated glass substrate in dry acetonitrile containing $0.1 \mathrm{M}$ of tetrabutylammonium perchlorate (TBAP) as an electrolyte exhibited one oxidation redox couples $\left(\mathrm{E}_{\text {onset }}\right)$ at $(1.32-1.38) \mathrm{V} v \mathrm{~s} \mathrm{Ag} / \mathrm{AgCl}$ and revealed electrochromic characteristics with a colour change from pale yellow to blue at applied potentials switched between 0.0 and $1.7 \mathrm{~V}$.
\end{abstract}

Keywords: Polyamides, Thermal, Spectral, Hole transporting, Characterization.

\section{INTRODUCTION}

Recently, the use of conjugated polymers in polymer lightemitting diodes (PLEDs), has received a great deal of concern in academia and the phoptoelectronic industry because of their several appealing advantages over other technologies. Polymer light-emitting diodes have been widely studied and the most efficient devices with a layered architecture reported are multilayer devices which comprise a sequence of a hole-transporting layer, an emitting layer and an electron-transporting layer ${ }^{1}$.

The field of organic light-emitting diodes (OLEDs) has attracted considerable interest as hole-transport materials for use in multi-layer organic electro-luminescence (EL) devices due to their relatively high mobilities and their low ionization potentials ${ }^{2-7}$. They are easily oxidized to form stable radical cations $^{8}$. In recent years, It had carried out extensive studies on the design and synthesis of triarylamine-based high performance polymers such as aromatic polyamides and polyimides for electro-chromic applications ${ }^{9}$. Many emitting materials have been designed and used in light emitting diodes. However, high-performance light emitting ones are rare because of the intrinsic wide band-gap required for such materials. Many hole transporting materials have been tried for light-emission ${ }^{10}$. Most of the hole-transporting materials which contain amine functionalities show lack sufficient emission characteristics due to reductive quenching ${ }^{11}$. Aromatic polyamides are well accepted as high-performance polymeric materials for their excellent mechanical properties, high thermal stability and good chemical resistance ${ }^{12}$. They are also known as difficult processing materials because of high melting or glass transition temperatures and limited solubility in most organic solvents. To overcome these limitations, polymer-structure modification becomes necessary such as the introduction of bulky, packingdisruptive groups into the polymer backbone ${ }^{13-16}$. It has been demonstrated that aromatic polyamides containing threedimensional, propeller-shaped triphenylamine unit had good solubility in organic solvents while retaining high thermal stability ${ }^{17-19}$. Furthermore, triphenylamine-based polymers are widely used as the hole-transport layer in electro-luminescence devices, but they also show interesting electrochromic behavior ${ }^{20-25}$.

The most common method for the preparation of aromatic polyamides is the reaction of diacid compounds with diamines at high temperatures. The solvents used are polar aprotic solvents like N,N-dimethylformamide (DMF), N,N-dimethy- 
lacetamide (DMAc), N-methyl pyrrolidone (NMP) and HMPA. Salts, such as $\mathrm{LiCl}, \mathrm{CaCl}_{2}$, or a mixture of both, are often used as solubility promoters because the cations interact with the amide groups, diminishing the strength of the interchain hydrogen bonds. The method was developed by Yamazaki et al. ${ }^{26}$.

Generally, a polymer light-emitting diode is a thin-film multilayer structure consists of a hole-transporting, an emitting and an electrontrans-porting layer sandwiched between two electrodes. Charge carriers (holes and electrons) are injected separately from anode and cathode, recombine in the emitting layer and thus emit light ${ }^{27}$.

In this paper, we have synthesized new poly(amineamide)s via phosphorylation polycondensation reaction to form newly synthesized monomers. The monomers and polymers characterized by FTIR, ${ }^{1} \mathrm{H}$ and ${ }^{13} \mathrm{C}$ NMR spectroscopic and thermal studies.

\section{EXPERIMENTAL}

4-Phenoxyaniline (Merck, 99.8\%), 4-(1H-pyrrol-1-yl)aniline, (Acros, 99.6\%), 4-fluorobenzonitrile (Acros, 98.7\%), sodium hydride (NaH) (Fluka, $60 \%)$, N,N-dimethyl-formamide (DMF) (Acros, $99.6 \%$ ), potassium hydroxide (KOH) (fluka, 99.8\%), ethanol (Merck, $99.7 \%$ ), acetic acid (Merck, $98 \%$ ), hydrochloric acid (Merck, $36 \%$ ), dimethyl sulfoxide- $\mathrm{D}_{6}$, (DMSO$\left.\mathrm{D}_{6}\right)$ (Merck, $99.8 \%$ ), chloroform- $d_{1},\left(\mathrm{CDCl}_{3}\right)$ (Merck, $\left.99.8 \%\right)$, p-phenylenediamine (Merck, $98 \%$ ), 1,5-diaminonaphthalene (Fluka, $98.8 \%$ ), pyridine (Merck, $97.8 \%$ ), triphenylphosphite (fluka, $99 \%$ ), calcium chloride (Merck, 99,6\%), N-methyl pyrrolidone (NMP) (Fluka, 99.6\%) were used without further purification. The FT-IR spectrum of the synthesized compounds were recorded with a Spotlight 400 Perkin Elmer spectrometer. ${ }^{1} \mathrm{H}$ NMR (400 MHz) and ${ }^{13} \mathrm{C}$ NMR (100 MHz) measurements were performed with a JEOL spectrometer. UV-visible absorption and photoluminescence spectra were recorded in $\mathrm{N}$-methylpyrrolidone with concentration (10-5 M) on a Cary $60 \mathrm{UV}$-visible pectrophotometer. Thermal data were obtained from a Perkin Elmer DSC6 instrument. The data were recorded under nitrogen atmosphere at a heating rate of $20^{\circ} \mathrm{C} / \mathrm{min}$ with a SDT Q600 thermogravimetric analyzer. The thermal decomposition data were recorded at a heating rate of $20{ }^{\circ} \mathrm{C} / \mathrm{min}$ under nitrogen atmosphere with a SDT Q600 thermogravimetric analyser (TGA Instrument).

\section{Monomer synthesis: The monomers (Ma-Mc) have synthesized via Scheme-I}

Synthesis of 4, 4'-dicyano-4"'-phenoxytriphenylamine (Ia): A mixture of $1.40 \mathrm{~g}(0.02 \mathrm{~mol})$ of sodium hydride and $80 \mathrm{~mL}$ of DMF was stirred for about $0.5 \mathrm{~h}$ at room temperature. To this mixture, $3.70 \mathrm{~g}(0.02 \mathrm{~mol})$ of 4-phenoxyaniline and $4.84 \mathrm{~g}(0.02 \mathrm{~mol})$ of 4 -fluorobenzonitrile were added in sequence. The mixture was heated with stirring at $120^{\circ} \mathrm{C}$ for $24 \mathrm{~h}$ under nitrogen and then precipitated into $150 \mathrm{~mL}$ of cold water ${ }^{28,29}$. The products were filtered and recrystallized from ethanol to give pale yellowish solid $5.27 \mathrm{~g}$ (yield: $62 \%$ ), m.p. $=140-142{ }^{\circ} \mathrm{C}$. FTIR $\left(v_{\max }, \mathrm{cm}^{-1}\right): 2213(\mathrm{C} \equiv \mathrm{N}) .{ }^{1} \mathrm{H}$ NMR $(400$ $\left.\mathrm{MHz}, \mathrm{CDCl}_{3}-d_{1}, \delta \mathrm{ppm}\right): 7.11\left(\mathrm{t}, 1 \mathrm{H}, \mathrm{H}_{\mathrm{a}}\right), 7.33\left(\mathrm{t}, 2 \mathrm{H}, \mathrm{H}_{\mathrm{b}}\right)$, $6.96\left(\mathrm{~d}, 2 \mathrm{H}, \mathrm{H}_{\mathrm{c}}\right), 7.02\left(\mathrm{~d}, 2 \mathrm{H}, \mathrm{H}_{\mathrm{d}}\right), 7.02\left(\mathrm{~d}, 2 \mathrm{H}, \mathrm{H}_{\mathrm{e}}\right), 7.06(\mathrm{~d}$, $\left.4 \mathrm{H}, \mathrm{H}_{\mathrm{f}}\right), 7.48\left(\mathrm{~d}, 4 \mathrm{H}, \mathrm{H}_{\mathrm{g}}\right) .{ }^{13} \mathrm{C} \mathrm{NMR}\left(400 \mathrm{MHz}, \mathrm{CDCl}_{3}-d_{1}, \delta\right.$ ppm): $124.04\left(\mathrm{C}_{1}\right), 129.93\left(\mathrm{C}_{2}\right), 119.41\left(\mathrm{C}_{3}\right), 156.24\left(\mathrm{C}_{4}\right)$, $150.11\left(\mathrm{C}_{5}\right), 119.86\left(\mathrm{C}_{6}\right), 128.63\left(\mathrm{C}_{7}\right), 139.55\left(\mathrm{C}_{8}\right), 150.44$ $\left(\mathrm{C}_{9}\right), 122.24\left(\mathrm{C}_{10}\right), 133.51\left(\mathrm{C}_{11}\right) .105 .60\left(\mathrm{C}_{12}\right), 118.87\left(\mathrm{C}_{\mathrm{CN}}\right)$.

Synthesis of 4, 4'-dicarboxy-4"'-phenoxytriphenylamine (Ma): A mixture of $15.5 \mathrm{~g}$ of potassium hydroxide and $8.50 \mathrm{~g}$ $(0.02 \mathrm{~mol})$ of the dinitrile compound (Ia) in $60 \mathrm{~mL}$ of ethanol and $60 \mathrm{~mL}$ of distilled water was stirred at about $100{ }^{\circ} \mathrm{C}$ until no further ammonia was generated. The time taken to reach this stage was about $24 \mathrm{~h}$. The solution was cooled and the $\mathrm{pH}$ value was adjusted by dilute hydrochloric acid to near 3 . The yellowish precipitate formed was collected by filtration, washed thoroughly with water. Recrystallization from acetic acid gave pale yellow crystals $6.80 \mathrm{~g}(80 \%$ yield $) ;$ m.p. $=215-218^{\circ} \mathrm{C}$. FTIR $\left(v_{\max }, \mathrm{cm}^{-1}\right): 1670(\mathrm{C}=\mathrm{O}), 3370(\mathrm{O}-\mathrm{H}),{ }^{1} \mathrm{H}$ NMR $(400$ $\left.\mathrm{MHz}, \mathrm{DMSO}-d_{6}, \delta \mathrm{ppm}\right): 11.25$ (s, 2H, $\left.\mathrm{H}_{\mathrm{COOH}}\right), 7.87$ (d, $4 \mathrm{H}$, $\left.\mathrm{H}_{\mathrm{g}}\right), 7.42\left(\mathrm{t}, 2 \mathrm{H}, \mathrm{H}_{\mathrm{b}}\right), 7.17\left(\mathrm{~m}, 3 \mathrm{H}, \mathrm{H}_{\mathrm{a}, \mathrm{e}}\right), 7.08-7.03(\mathrm{~m}, 8 \mathrm{H}$, $\left.\mathrm{H}_{\mathrm{c}, \mathrm{d}, \mathrm{f}}\right) .{ }^{13} \mathrm{C} \mathrm{NMR}\left(400 \mathrm{MHz}, \mathrm{DMSO}-d_{6}, \delta \mathrm{ppm}\right): 166.66$ $(\mathrm{COOH}), 156.09\left(\mathrm{C}_{8}\right), 145.322\left(\mathrm{C}_{1}\right), 155.09\left(\mathrm{C}_{9}\right), 140.52\left(\mathrm{C}_{5}\right)$, $130.77\left(\mathrm{C}_{11}\right), 129.94\left(\mathrm{C}_{2}\right), 128.41\left(\mathrm{C}_{7}\right), 124.49\left(\mathrm{C}_{4}\right), 123.60$ $\left(\mathrm{C}_{12}\right), 121.46\left(\mathrm{C}_{10}\right) 119.66\left(\mathrm{C}_{6}\right) 118.78\left(\mathrm{C}_{3}\right)$.

Synthesis of 4, 4'-dicyano-4"'-(1H-pyrrol-1-yl)triphenylamine(Ib): The synthesis of this compound was the same to that for (Ia) but using 4-(1H-pyrrol-1-yl)aniline. The product was filtered and recrystallized from ethanol to give pale yellowish solid $5.50 \mathrm{~g}$ (yield: $76 \%$ ), m.p. $=148-150{ }^{\circ} \mathrm{C}$. FTIR $\left(v_{\max }, \mathrm{cm}^{-1}\right): 2219.4(\mathrm{C} \equiv \mathrm{N}) .{ }^{1} \mathrm{H}$ NMR $\left(400 \mathrm{MHz}, \mathrm{CDCl}_{3}-d_{1}, \delta\right.$ ppm): $7.47\left(\mathrm{~d}, 4 \mathrm{H}, \mathrm{H}_{\mathrm{f}}\right), 7.33\left(\mathrm{~d}, 2 \mathrm{H}, \mathrm{H}_{\mathrm{b}}\right), 7.11\left(\mathrm{~d}, 2 \mathrm{H}, \mathrm{H}_{\mathrm{c}}\right), 7.06$ $\left(\mathrm{d}, 4 \mathrm{H}, \mathrm{H}_{\mathrm{e}}\right), 7.00\left(\mathrm{t}, 2 \mathrm{H}, \mathrm{H}_{\mathrm{d}}\right), 6.29\left(\mathrm{t}, 2 \mathrm{H}, \mathrm{H}_{\mathrm{a}}\right) .{ }^{13} \mathrm{C} \mathrm{NMR}(400$ $\left.\mathrm{MHz}, \mathrm{CDCl}_{3}-d_{1}, \delta \mathrm{ppm}\right): 150.03\left(\mathrm{C}_{7}\right), 142.32\left(\mathrm{C}_{6}\right), 138.84\left(\mathrm{C}_{3}\right)$, $133.69\left(\mathrm{C}_{9}\right), 128.04\left(\mathrm{C}_{5}\right), 122.92\left(\mathrm{C}_{8}\right), 122.05\left(\mathrm{C}_{4}\right), 119.24$ $\left(\mathrm{C}_{2}\right), 118.85\left(\mathrm{C}_{\mathrm{CN}}\right), 111.03\left(\mathrm{C}_{1}\right), 106.12\left(\mathrm{C}_{10}\right)$.

Synthesis of 4,4'-dicarboxy-4"'-(1H-pyrrol-1-yl)triphenylamine(Mb): Synthesis of this compoundwas the same to that for (Ma). The pale yellow crystals $7.00 \mathrm{~g}$ (89\% yield); m.p. $=229-232{ }^{\circ} \mathrm{C}$. FTIR $\left(v_{\max }, \mathrm{cm}^{-1}\right): 1681(\mathrm{C}=\mathrm{O}), 2700-3300$ (O-H). ${ }^{1} \mathrm{H}$ NMR (400 MHz, DMSO- $d_{6}, \delta$ ppm): 11.25 (s,2H, $\left.\mathrm{H}_{\mathrm{COOH}}\right), 7.89\left(\mathrm{~d}, 4 \mathrm{H}, \mathrm{H}_{\mathrm{f}}\right), 7.64\left(\mathrm{t}, 2 \mathrm{H}, \mathrm{H}_{\mathrm{b}}\right), 7.37\left(\mathrm{~d}, 2 \mathrm{H}, \mathrm{H}_{\mathrm{d}}\right)$, $7.24\left(\mathrm{~d}, 2 \mathrm{H}, \mathrm{H}_{\mathrm{c}}\right), 7.11\left(\mathrm{~d}, 4 \mathrm{H}, \mathrm{H}_{\mathrm{e}}\right), 6.29\left(\mathrm{t}, 2 \mathrm{H}, \mathrm{H}_{\mathrm{a}}\right) .{ }^{13} \mathrm{C} \mathrm{NMR}$ (400 MHz, DMSO- $d_{6}, \delta$ ppm): $166.85(\mathrm{CCOOH}), \mathrm{C}_{7}(150.25)$, $\mathrm{C}_{6}(142.59), \mathrm{C}_{3}(137.25), \mathrm{C}_{9}(131.05), \mathrm{C}_{5}(127.77), \mathrm{C}_{10}(124.65)$, $\mathrm{C}_{8}$ (122.02), $\mathrm{C}_{4}$ (120.91), $\mathrm{C}_{2}$ (118.99), $\mathrm{C}_{1}$ (110.64).

Synthesis of 4,4',4",4'"'-(1,4-phenylenebis(azanetriyl)) tetrabenzonitrile (Ic): Synthesis of this compound was same to that for (Ia) using $p$-phenylenediamine resulting in a pale yellowish solid $4.10 \mathrm{~g}$ (yield: $88 \%$ ), m.p. $=150-152^{\circ} \mathrm{C}$. FTIR $\left(v_{\max }, \mathrm{cm}^{-1}\right): 2222(\mathrm{C} \equiv \mathrm{N}) .{ }^{1} \mathrm{H}$ NMR $\left(400 \mathrm{MHz}, \mathrm{CDCl}_{3}-d_{1}, \delta\right.$ ppm): $7.62\left(\mathrm{~d}, 8 \mathrm{H}, \mathrm{H}_{\mathrm{c}}\right), 7.04\left(\mathrm{~d}, 8 \mathrm{H}, \mathrm{H}_{\mathrm{b}}\right), 6.84\left(\mathrm{~s}, 4 \mathrm{H}, \mathrm{H}_{\mathrm{a}}\right) .{ }^{13} \mathrm{C}$ NMR (400 MHz, $\left.\mathrm{CDCl}_{3}-d_{1}, \delta \mathrm{ppm}\right): 159.22\left(\mathrm{C}_{3}\right), 138.21\left(\mathrm{C}_{2}\right)$, $135.88\left(\mathrm{C}_{1}\right), 134.48\left(\mathrm{C}_{5}\right), 119.69\left(\mathrm{C}_{4}\right), 118.22\left(\mathrm{C}_{\mathrm{CN}}\right), 108.04\left(\mathrm{C}_{6}\right)$

Synthesis of 4,4',4"4'"'-(1,4-phenylenebis-((azanetriyl)))tetrabenzoic acid (Mc): Synthesis compound (Mc) was the same to that for (Ma) using (Ic) giving pale yellow crystals, 4.86 g $(90 \%$ yield $) ;$ m.p. $=287-290{ }^{\circ} \mathrm{C}$. FTIR $\left(v_{\max }, \mathrm{cm}^{-1}\right): 1682$ $(\mathrm{C}=\mathrm{O}), 3378(\mathrm{O}-\mathrm{H}) .{ }^{1} \mathrm{H}$ NMR $\left(400 \mathrm{MHz}, \mathrm{DMSO}-d_{6}, \delta \mathrm{ppm}\right)$ : 12.23 (s, 2H, $\left.\mathrm{HC}_{\mathrm{OOH}}\right), 7.91\left(\mathrm{~d}, 8 \mathrm{H}, \mathrm{H}_{\mathrm{c}}\right), 7.04\left(\mathrm{~d}, 8 \mathrm{H}, \mathrm{H}_{\mathrm{b}}\right), 6.52$ $\left(\mathrm{s}, 4 \mathrm{H}, \mathrm{H}_{\mathrm{a}}\right) .{ }^{13} \mathrm{C}$ NMR $\left(400 \mathrm{MHz}\right.$, DMSO- $\left.d_{6}\right): 166.78\left(\mathrm{C}_{\mathrm{COOH}}\right)$, $158.34\left(\mathrm{C}_{3}\right), 137.14\left(\mathrm{C}_{2}\right), 134.78\left(\mathrm{C}_{1}\right), 133.04\left(\mathrm{C}_{5}\right) 123.30\left(\mathrm{C}_{6}\right)$, $118.12\left(\mathrm{C}_{4}\right)$. 


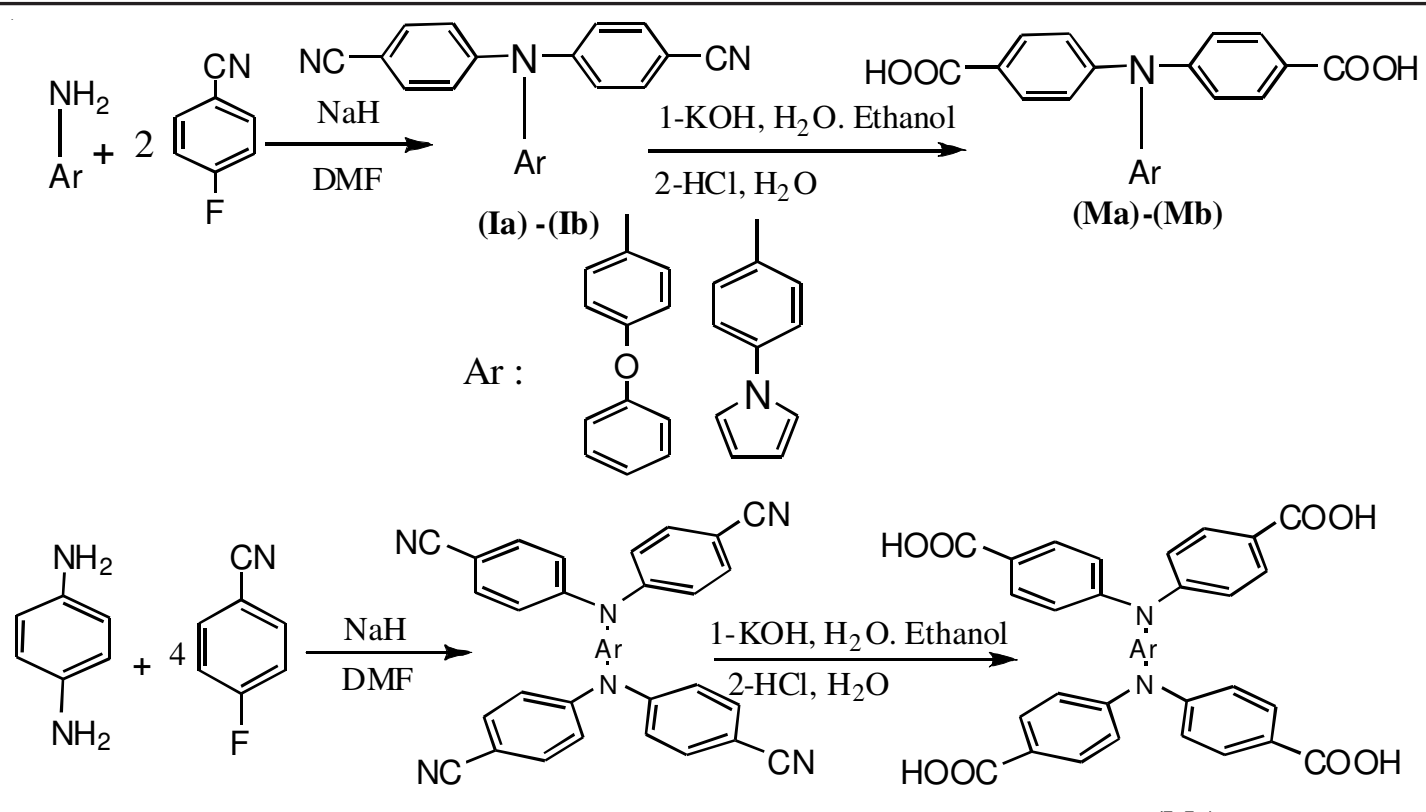

(Ic)

(Mc)

Scheme-I: Synthesis routes of monomers

\section{Polymer synthesis}

Synthesis of poly(amine-amide) (pa1): The polymers (pa1-pc1, pa2-pc2) have been been synthesized via the routes as explained in the Scheme-II. The synthesis of poly(amineamide) (pa1) is used as an example to illustrate the general synthetic route Scheme-II. The typical procedure is as follows:

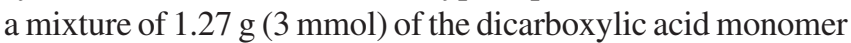
(Ma), $0.324 \mathrm{~g}$ ( $3 \mathrm{mmol})$ of $p$-phenylenediamine, $0.4 \mathrm{~g}$ of calcium chloride $\left(\mathrm{CaCl}_{2}\right), 4.5 \mathrm{~mL}$ of triphenylphosphite (TPP), $1.5 \mathrm{~mL}$ of pyridine, and $4.5 \mathrm{~mL}$ of $\mathrm{N}$-methyl-2-pyrrolidone (NMP) as a solvent was heated with stirring at $105^{\circ} \mathrm{C}$ for $3 \mathrm{~h}$. The resulting viscous polymer solution was poured slowly into $300 \mathrm{~mL}$ of stirring methanol giving rise to a stringy, fiber-like precipitate that was collected by filtration, washed thoroughly with hot water and methanol and dried at $80{ }^{\circ} \mathrm{C}$ for $24 \mathrm{~h}$. The inherent viscosity of the obtained poly(amine-amide) was 0.42 $\mathrm{dL} / \mathrm{g}$, measured at a concentration of $0.5 \mathrm{~g} / \mathrm{dL}$ in DMAc. The IR spectrum exhibited characteristic amide absorption bands at $3376 \mathrm{~cm}^{-1}$ (N-H stretching) and $1648 \mathrm{~cm}^{-1}$ (amide carbonyl). ${ }^{1} \mathrm{H}$ NMR (400 MHz, DMSO- $d_{6}, \delta$ ppm): 10.14 (s, $1 \mathrm{H}, \mathrm{H}_{\mathrm{NH}-\mathrm{CO}}$ ), $7.91\left(\mathrm{~d}, 4 \mathrm{H}, \mathrm{H}_{\mathrm{g}}\right), 7.71\left(\mathrm{~s}, 4 \mathrm{H}, \mathrm{H}_{\mathrm{h}}\right), 7.41\left(\mathrm{t}, 1 \mathrm{H}, \mathrm{H}_{\mathrm{a}}\right), 7.18(\mathrm{t}, 2 \mathrm{H}$, $\left.\mathrm{H}_{\mathrm{b}}\right),\left(\mathrm{m}, 10 \mathrm{H}, \mathrm{H}_{\mathrm{d}, \mathrm{e}, \mathrm{f}}\right), 6.96\left(\mathrm{~d}, 2 \mathrm{H}, \mathrm{H}_{\mathrm{c}}\right) .{ }^{13} \mathrm{C} \mathrm{NMR}(400 \mathrm{MHz}$, DMSO- $\left.d_{6}, \delta \mathrm{ppm}\right): 166.95\left(\mathrm{C}_{\mathrm{CONH}}\right), 157.70\left(\mathrm{C}_{14}\right), 156.37\left(\mathrm{C}_{4}\right)$, 149.45( $\left.\mathrm{C}_{5}\right), 148.63\left(\mathrm{C}_{13}\right), 150.89\left(\mathrm{C}_{9}\right), 142.61\left(\mathrm{C}_{8}\right), 131.08$ $\left(\mathrm{C}_{11}\right), 130.25\left(\mathrm{C}_{7}\right), 128.77\left(\mathrm{C}_{2}\right), 124.57\left(\mathrm{C}_{1}\right), 123.88\left(\mathrm{C}_{12}\right)$, $121.76\left(\mathrm{C}_{10}\right), 120.00\left(\mathrm{C}_{3}\right), 119.12\left(\mathrm{C}_{6}\right)$.

Synthesis of poly(amine-amide) (pb1): The polymer (pb1) was synthesized by the same method which was described in synthesis of (pa1) but using (Mb1). The obtained poly(amine-amide) was $0.46 \mathrm{dL} / \mathrm{g}$, measured at a concentration of $0.5 \mathrm{~g} / \mathrm{dL}$ in DMAc. The IR spectrum gave bands at 3373 $\mathrm{cm}^{-1}$ (N-H stretching) and 1648 (amide carbonyl). ${ }^{1} \mathrm{H}$ NMR (400 MHz, DMSO- $d_{6}, \delta$ ppm): 10.24 (s, 1H, $\mathrm{H}_{\mathrm{NH}-\mathrm{C}=\mathrm{O}}$ ), 7.98 $\left(\mathrm{d}, 4 \mathrm{H}, \mathrm{H}_{\mathrm{f}}\right), 7.73-7.62\left(\mathrm{~m}, 8 \mathrm{H}, \mathrm{H}_{\mathrm{g}, \mathrm{c}, \mathrm{b}}\right), 7.36\left(\mathrm{~d}, 2 \mathrm{H}, \mathrm{H}_{\mathrm{d}}\right), 7.17(\mathrm{~d}$, $\left.2 \mathrm{H}, \mathrm{H}_{\mathrm{e}}\right), 6.27\left(\mathrm{~s}, 2 \mathrm{H}, \mathrm{H}_{\mathrm{a}}\right) .{ }^{13} \mathrm{C}$ NMR $\left(400 \mathrm{MHz}, \mathrm{DMSO}-d_{6}, \delta\right.$ $\mathrm{ppm})$ : 164.68 ( $\left.\mathrm{C}_{\mathrm{CONH}-}\right), 150.05\left(\mathrm{C}_{7}\right), 143.11\left(\mathrm{C}_{6}\right), 138.12\left(\mathrm{C}_{3}\right)$,
$134.75\left(\mathrm{C}_{11}\right), 130.06\left(\mathrm{C}_{9}\right), 127.16\left(\mathrm{C}_{5}\right), 124.18\left(\mathrm{C}_{10}\right), 122.34$ $\left(\mathrm{C}_{8}\right), 120.60\left(\mathrm{C}_{12}\right), 118.09\left(\mathrm{C}_{4}\right), 118.42\left(\mathrm{C}_{2}\right), 110.49\left(\mathrm{C}_{1}\right)$.

Synthesis of poly(amine-amide) (pc1): This polymer was synthesized from (Mc1) by the same method which was described in synthesis of pa1. The obtained poly(amineamide) was $0.43 \mathrm{dL} / \mathrm{g}$, measured at a concentration of $0.5 \mathrm{~g} /$ $\mathrm{dL}$ in DMAc. The IR spectrum exhibited bands at $3264 \mathrm{~cm}^{-1}$ (N-H stretching) and $1647 \mathrm{~cm}^{-1}$ (amide carbonyl). ${ }^{1} \mathrm{HNMR}$ (400 MHz, DMSO- $\left.d_{6}, \delta \mathrm{ppm}\right): 10.30\left(\mathrm{~s}, 1 \mathrm{H}, \mathrm{H}_{\mathrm{NH}-\mathrm{C}=\mathrm{O}}\right), 8.10$ (s, $\left.8 \mathrm{H}, \mathrm{H}_{\mathrm{C}}\right), 7.79\left(\mathrm{~s}, 4 \mathrm{H}, \mathrm{H}_{\mathrm{d}}\right), 7.42-7.24\left(\mathrm{~d}, 8 \mathrm{H}, \mathrm{H}_{\mathrm{b}}\right), 6.61(\mathrm{~s}, 4 \mathrm{H}$, $\left.\mathrm{H}_{\mathrm{a}}\right) .{ }^{13} \mathrm{C}$ NMR $\left(400 \mathrm{MHz}, \mathrm{DMSO}-d_{6}, \delta \mathrm{ppm}\right): 164.94\left(\mathrm{C}_{\mathrm{CO}-\mathrm{NH}}\right)$. $158.75\left(\mathrm{C}_{3}\right), 145.26\left(\mathrm{C}_{7}\right), 135.43\left(\mathrm{C}_{2}\right) .131 .35\left(\mathrm{C}_{1}\right) .130 .52$ $\left(\mathrm{C}_{5}\right) .122 .74\left(\mathrm{C}_{6}\right) .121 .15\left(\mathrm{C}_{8}\right) .118 .93\left(\mathrm{C}_{4}\right)$.

Synthesis of poly(amine-amide) (pa2): This polymer (pa2) was synthesized by the same method which was used in synthesis of (Pa1) but used 1,5-diamine naphthalene instead of $p$-phenylenediamine. The inherent viscosity of the obtained poly (amine-amide) was $0.65 \mathrm{dL} / \mathrm{g}$, measured at a concentration of $0.5 \mathrm{~g} / \mathrm{dL}$ in DMAc. The IR spectrum exhibited characteristic amide absorption bands at $3372 \mathrm{~cm}^{-1}$ (N-H stretching) and 1646 $\mathrm{cm}^{-1}$ (amide carbonyl). ${ }^{1} \mathrm{H}$ NMR (400 MHz, DMSO- $d_{6}, \delta \mathrm{ppm}$ ): 10.40 (s, $\left.1 \mathrm{H}, \mathrm{H}_{\mathrm{NH}-\mathrm{CO}}\right), 8.10-8.07$ (m, 4H, $\mathrm{H}_{\mathrm{g}, \mathrm{i}}$ ), 7.93-7.91 (d, $\left.2 \mathrm{H}, \mathrm{H}_{\mathrm{j}}\right), 7.61-7.56\left(\mathrm{t}, 2 \mathrm{H}, \mathrm{H}_{\mathrm{b}}\right), 7.45-7.41\left(\mathrm{~m}, 3 \mathrm{H}, \mathrm{H}_{\mathrm{a}, \mathrm{c}}\right), 7.26-$ $7.17\left(\mathrm{~m}, 8 \mathrm{H}, \mathrm{H}_{\mathrm{h}, \mathrm{fe}}\right), 7.11-7.09\left(\mathrm{~d}, 2 \mathrm{H}, \mathrm{H}_{\mathrm{d}}\right) .{ }^{13} \mathrm{C} \mathrm{NMR}(400 \mathrm{MHz}$, DMSO- $d_{6}, \delta$ ppm): $165.63\left(\mathrm{C}_{\mathrm{CONH}}\right), 156.54\left(\mathrm{C}_{4}\right), 150.59\left(\mathrm{C}_{9}\right)$, $149.71\left(\mathrm{C}_{5}\right), 141.25\left(\mathrm{C}_{8}\right), 131.97\left(\mathrm{C}_{13}\right), 130.21\left(\mathrm{C}_{11}\right), 129.57$ $\left(\mathrm{C}_{7}\right), 128.30\left(\mathrm{C}_{2}\right), 125.49\left(\mathrm{C}_{15}\right), 124.23\left(\mathrm{C}_{1}\right), 123.77\left(\mathrm{C}_{12}\right)$, $121.94\left(\mathrm{C}_{10}\right), 120.77\left(\mathrm{C}_{17}\right), 120.07\left(\mathrm{C}_{3}\right), 118.88\left(\mathrm{C}_{6}\right), 111.82$ $\left(\mathrm{C}_{16}\right), 107.87\left(\mathrm{C}_{14}\right)$.

Synthesis of poly(amine-amide) (pb2): This polymer (pb2) was synthesized from (Mb1) by the same method which was described in synthesis of (pa1). The inherent viscosity of the obtained poly(amine-amide) was $0.48 \mathrm{dL} / \mathrm{g}$, measured at a concentration of $0.66 \mathrm{~g} / \mathrm{dL}$ in DMAc. The IR spectrum exhibited characteristic amide absorption bands at $3370 \mathrm{~cm}^{-1}$ (N-H stretching) and $1646 \mathrm{~cm}^{-1}$ (amide carbonyl). ${ }^{1} \mathrm{H}$ NMR 


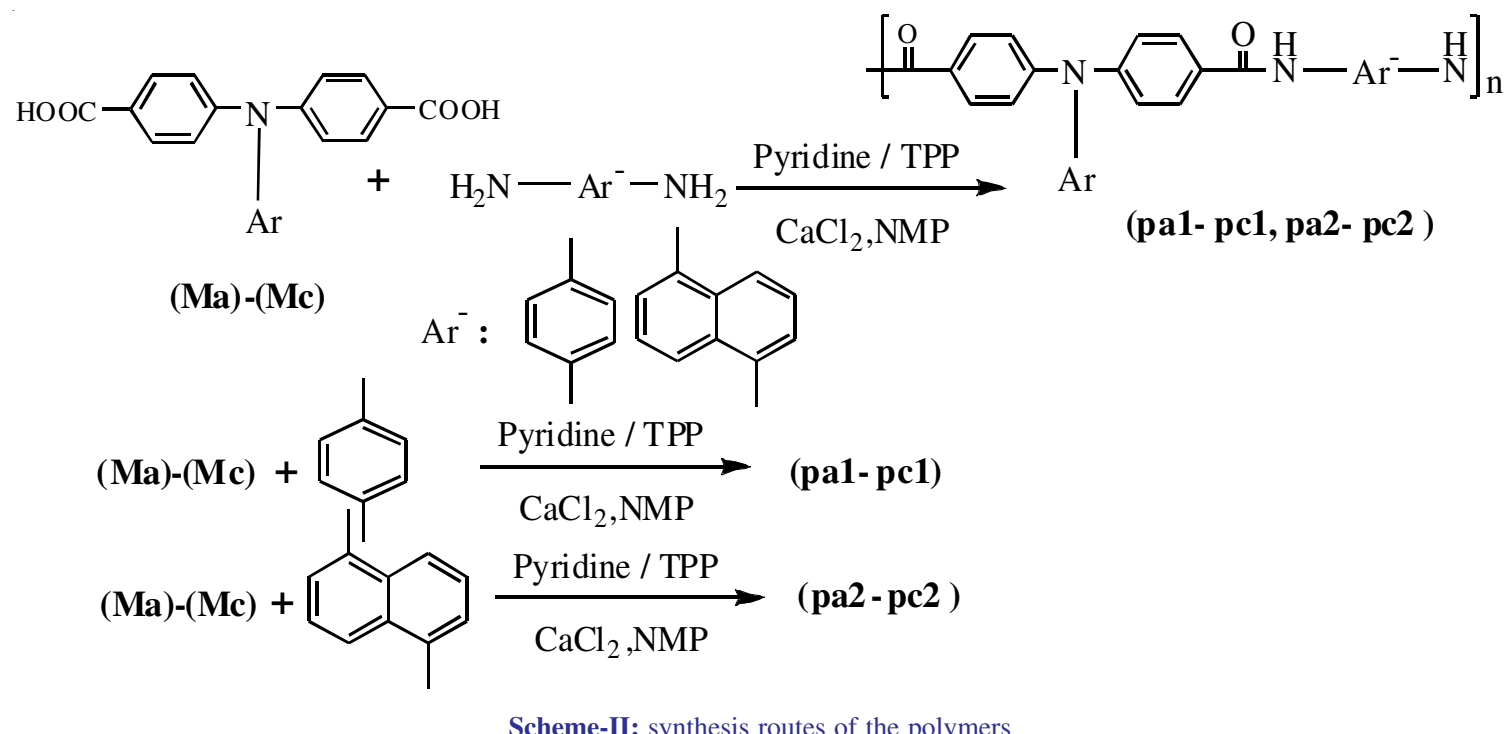

(400 MHz, DMSO- $d_{6}, \delta$ ppm): $10.45\left(\mathrm{~s}, 1 \mathrm{H}, \mathrm{H}_{\mathrm{NH}-\mathrm{CO}}\right), 8.12-$ $7.94\left(\mathrm{~m}, 6 \mathrm{H}, \mathrm{H}_{\mathrm{f}, \mathrm{i}}\right), 7.69-7.65\left(\mathrm{~m}, 6 \mathrm{H}, \mathrm{H}_{\mathrm{b}, \mathrm{c}, \mathrm{h}}\right), 7.39-7.22(\mathrm{~m}, 8 \mathrm{H}$, $\left.\mathrm{H}_{\mathrm{d}, \mathrm{e}, \mathrm{g}}\right), 6.29\left(\mathrm{~s}, 2 \mathrm{H}, \mathrm{H}_{\mathrm{a}}\right) .{ }^{13} \mathrm{C} \mathrm{NMR}\left(400 \mathrm{MHz}, \mathrm{DMSO}-d_{6}, \delta\right.$ ppm): $166.06\left(\mathrm{C}_{\mathrm{CONH}}\right), 150.08\left(\mathrm{C}_{7}\right), 143.59\left(\mathrm{C}_{6}\right), 137.45\left(\mathrm{C}_{11}\right)$, $134.85\left(\mathrm{C}_{3}\right), 130.13\left(\mathrm{C}_{9}\right), 128.84\left(\mathrm{C}_{10}\right), 127.74\left(\mathrm{C}_{13}\right), 124.56$ $\left(\mathrm{C}_{5}\right), 122.77\left(\mathrm{C}_{2}\right), 121.12\left(\mathrm{C}_{4}\right), 119.57\left(\mathrm{C}_{8}\right), 119.14\left(\mathrm{C}_{15}\right)$, $111.23\left(\mathrm{C}_{14}\right), 108.21\left(\mathrm{C}_{1}\right), 103.34\left(\mathrm{C}_{12}\right)$.

Synthesis of poly(amine-amide) (pc2): This polymer (PC2) was synthesized by the same method which was described in synthesis of (pa2) using (Mc1). The inherent viscosity of the obtained poly(amine-amide) was $0.48 \mathrm{dL} / \mathrm{g}$, measured at a concentration of $0.71 \mathrm{~g} / \mathrm{dL}$ in DMAc. The IR spectrum exhibited characteristic amide absorption bands at $3370 \mathrm{~cm}^{-1}$ (N-H stretching) and $1644 \mathrm{~cm}^{-1}$ (amide carbonyl). ${ }^{1} \mathrm{H}$ NMR (400 MHz, DMSO- $d_{6}, \delta$ ppm): 10.53 (s, $1 \mathrm{H}, \mathrm{H}_{\mathrm{NH}-\mathrm{CO}}$ ), 8.23$821\left(\mathrm{~d}, 8 \mathrm{H}, \mathrm{H}_{\mathrm{c}}\right), 7.98-7.96\left(\mathrm{~d}, 2 \mathrm{H}, \mathrm{H}_{\mathrm{e}}\right), 7.63-7.59\left(\mathrm{~d}, 2 \mathrm{H}, \mathrm{H}_{\mathrm{f}}\right)$, 7.18-7.16 (d, 2H, $\left.\mathrm{H}_{\mathrm{d}}\right), 6.74\left(\mathrm{~s}, 4 \mathrm{H}, \mathrm{H}_{\mathrm{a}}\right) .{ }^{13} \mathrm{C} \mathrm{NMR}(400 \mathrm{MHz}$, DMSO- $\left.d_{6}, \delta \mathrm{ppm}\right): 165.90\left(\mathrm{C}_{\mathrm{CO}-\mathrm{NH}}\right), 159.34\left(\mathrm{C}_{3}\right), 134.62\left(\mathrm{C}_{7}\right)$, $132.30\left(\mathrm{C}_{2}\right), 130.78\left(\mathrm{C}_{5}\right), 126.02\left(\mathrm{C}_{9}\right), 122.45\left(\mathrm{C}_{6}\right), 119.60$ $\left(\mathrm{C}_{11}\right), 119.09\left(\mathrm{C}_{4}\right), 118.69\left(\mathrm{C}_{10}\right), 115.67\left(\mathrm{C}_{8}\right)$.

\section{RESULTS AND DISCUSSION}

Monomer synthesis: The new aromatic dicarboxylic acid having 4-phenoxy substituted triphenylamine unit, 4,4'dicarboxy-4"-phenoxy triphenylamine (Ma), was synthesized by the amination reaction of 4-phenoxylaniline with 4fluorobenzonitrile, followed by the alkaline hydrolysis of the intermediate dicyano compound (Ia) and according to the synthetic routes outlined in Scheme-I.

FTIR, ${ }^{1} \mathrm{H}$ and ${ }^{13} \mathrm{C}$ NMR spectroscopic techniques were used to identify the chemical structures of the intermediate dicyano compound (Ia) and the dicarboxylic acid monomer (Ma). The FTIR spectra of compound (Ia) gave a cyano group characteristic band at $2213 \mathrm{~cm}^{-1}$ (CN-stretching). After hydrolysis, the cyano group absorption peak disappeared and the carboxylic acid group showed a typical carbonyl absorption band at $1670 \mathrm{~cm}^{-1}(\mathrm{C}=\mathrm{O}$ stretching $)$ together with the appearance of broad bands around $3400-2700 \mathrm{~cm}^{-1}$ (O-H stretching) (Fig. 1).

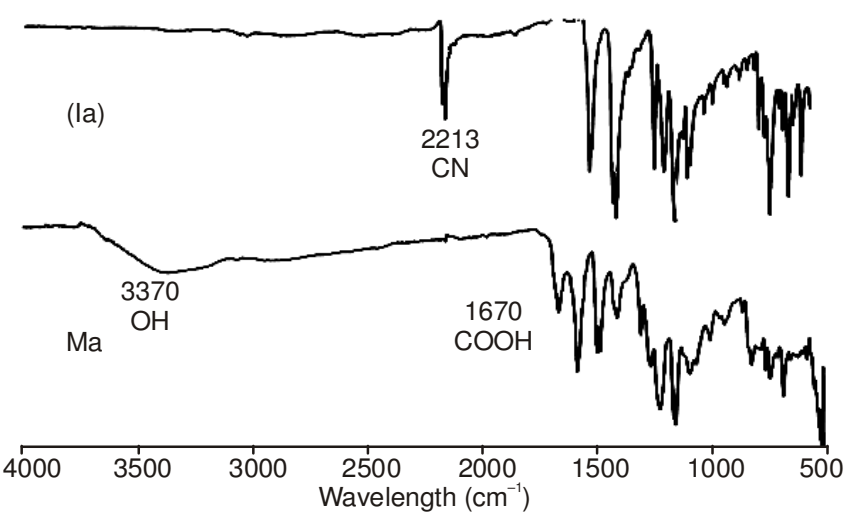

Fig. 1. FTIR spectrum of compounds (Ia), (Ma)

Structures of compounds (Ia) and (Ma) were also confirmed by high-resolution NMR spectra (Fig. 2 and 3). In ${ }^{1} \mathrm{H}$ NMR spectrum (Fig. 2), a big doublet peak at 7.48 (d, 4H, $\mathrm{H}_{\mathrm{g}}$ ) due to four phenylene protons $(\mathrm{g})$ and triplet peaks at $7.11(\mathrm{t}$, $1 \mathrm{H}, \mathrm{H}_{\mathrm{a}}$ ) and $7.33\left(\mathrm{t}, 2 \mathrm{H}, \mathrm{H}_{\mathrm{b}}\right)$ due to two protons of (a) and (b), respectively together with peak of two protons of each e, $d$ and four protons of (f). Doublet peak at $6.96\left(\mathrm{~d}, 2 \mathrm{H}, \mathrm{H}_{\mathrm{c}}\right)$ for two protons of (c) are also observed. Fig. 3 exhibits very broad singlet peak due to proton of carboxylic group which is hardly observed because of replacement hydrogen atoms of $(\mathrm{COOH})$ by deuterium of DMSO solvent and formation of $\mathrm{H}$-bonding and multiplet peak of (c, d, e, f) protons. The ${ }^{13} \mathrm{C}$ NMR spectra (Fig. 4) confirmed that the chemical shifting of C-atoms and that the cyano groups were completely converted into the carboxylic acid groups by the disappearance of the resonance peak for the cyano carbon at $105.60 \mathrm{ppm}$ and by the appearance of the carboxyllic peak at $166.66 \mathrm{ppm}$.

Other important evidence of this change is the shifting of the carbon resonance signals of $\mathrm{C}_{12}$ adjacent to the cyano or carboxyl group. The $\mathrm{C}_{12}$ of dinitrile (1) resonated at a higher field $(105.60 \mathrm{ppm})$ than the other aromatic carbons because of the anisotropic shielding by the $\pi$-electrons of $\mathrm{C}=\mathrm{N}$. After hydrolysis, the resonance peak of $\mathrm{C}_{12}$ shifted to a lower field $(123.60 \mathrm{ppm})$ because of the lack of an anisotropic field (Fig. 5). 


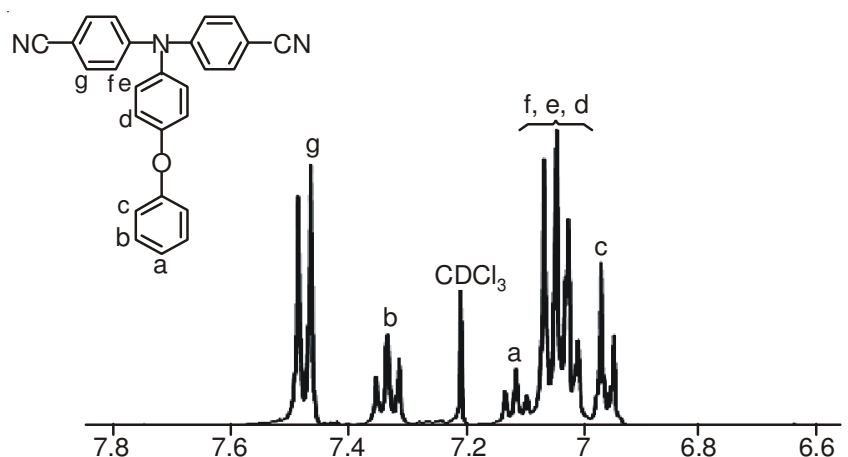

Fig. 2. ${ }^{1} \mathrm{H}$ NMR spectrum of compound (Ia) in $\mathrm{CDCl}_{3}-d_{1}$

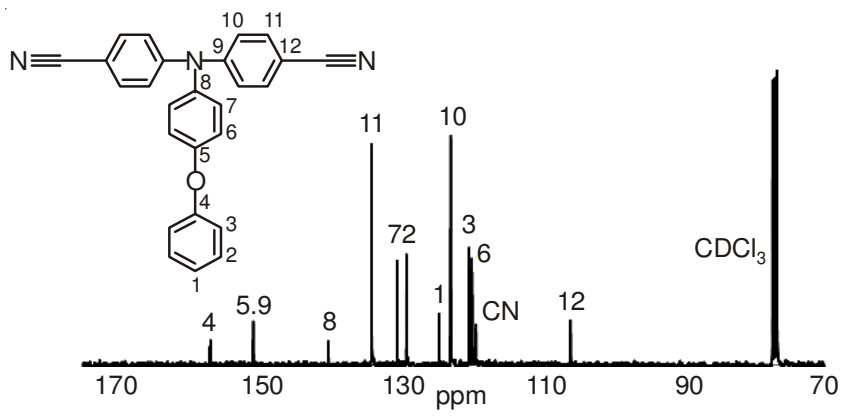

Fig. $3 .{ }^{13} \mathrm{C}-\mathrm{NMR}$ spectrum of compound (Ia) in $\mathrm{CDCl}_{3}-d_{1}$

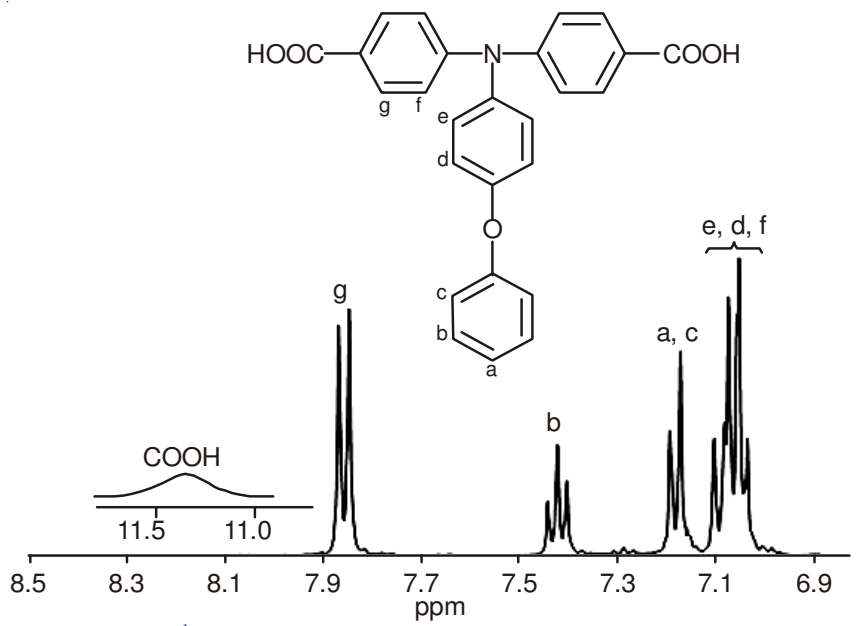

Fig. 4. ${ }^{1} \mathrm{H}-\mathrm{NMR}$ spectrum of compound (Ma) in $\mathrm{CDCl}_{3}-d_{1}$

Polymer synthesis: A series of new aromatic poly(amineamide)s with aryltriphenylamine (ATPA) units were prepared by the direct polycondensation reactions of the dicarboxylic

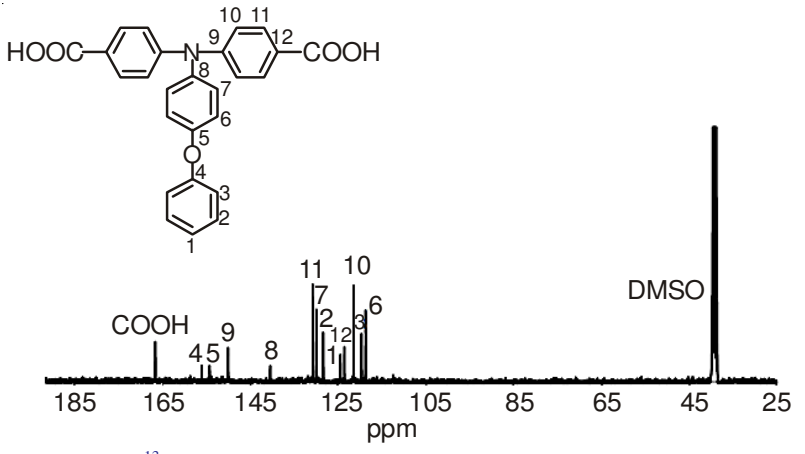

Fig. $5 .{ }^{13} \mathrm{C}-\mathrm{NMR}$ spectrum of compound (Ma) in DMSO- $d_{6}$

acid monomer (Ma) With various aromatic diamines, $p$-phenylenediamine, 1,5-diaminonaphthalene using triphenylphosphite (TPP) and pyridine as condensing agents (Scheme-III).

All the polymerizations proceeded homogeneously throughout the reaction and afforded clear, highly viscous polymer solutions. These polymers precipitated in a tough, fiber-like form when the resulting polymer solutions were slowly poured with stirring into methanol. These poly(amineamide)s were obtained in almost quantitative yields, with $\eta_{\text {inh }}$ values in the range of $0.42-0.71 \mathrm{dL} / \mathrm{g}$ (Table- 1 ). All the polymers can be solvent cast into flexible and tough films. Structural features of these poly(amine-amide)s were verified by FTIR and NMR spectroscopies. The characteristic absorption bands were observed around $3376\left(\mathrm{~N}-\mathrm{H}\right.$ stretching) and $1648 \mathrm{~cm}^{-1}$ ( $\mathrm{C}=\mathrm{O}$ stretching of amide group). Fig. 6 illustrates a typical FTIR spectrum of the representative poly(amine-amide) (pa1). ${ }^{1} \mathrm{H}$ and ${ }^{13} \mathrm{C}$ NMR spectra of polyamide in DMSO- $d_{6}$ agree well with the proposed molecular structure of (pa1).

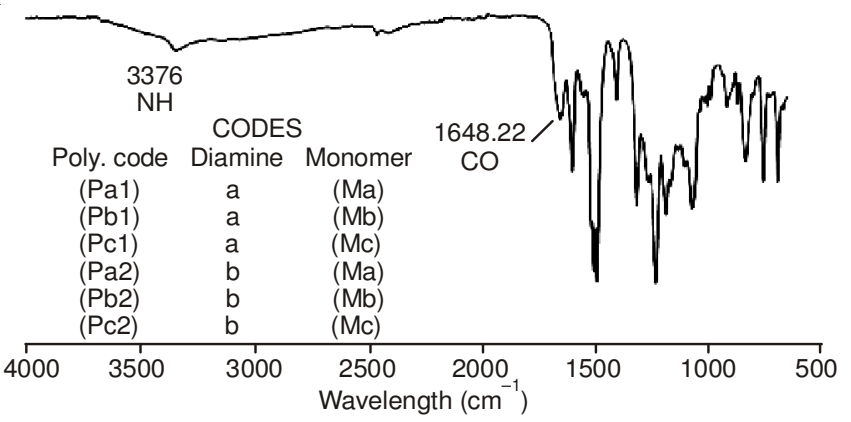

Fig. 6. FTIR spectrum of poly (amine-amide) (pa1)<smiles>CC(C)(C)C1CCCC1</smiles><smiles>C/C=C\C=C/[In](N)NN</smiles>

(a)<smiles>Cc1cccc2c(C)cccc12</smiles>

(b) 
Fig. 7 exhibits singlet band at $10.14\left(\mathrm{~s}, 1 \mathrm{H}, \mathrm{H}_{\mathrm{NH}-\mathrm{CO}}\right)$ of proton of the amide group resulting after polymerization and doublet peak at $7.91\left(\mathrm{~d}, 4 \mathrm{H}, \mathrm{H}_{\mathrm{g}}\right)$ of proton $(\mathrm{g})$. Singlet peak at $7.71\left(\mathrm{~s}, 4 \mathrm{H}, \mathrm{H}_{\mathrm{h}}\right)$ of four protons of $(\mathrm{h})$ and triplet peaks at 7.41 $\left(\mathrm{t}, 1 \mathrm{H}, \mathrm{H}_{\mathrm{a}}\right)$ and $7.18\left(\mathrm{t}, 2 \mathrm{H}, \mathrm{H}_{\mathrm{b}}\right)$ of two protons of each (a) and (b), respectively. Together peaks at $\left(\mathrm{m}, 10 \mathrm{H}, \mathrm{H}_{\mathrm{c}, \mathrm{d}, \mathrm{e}, \mathrm{f}}\right)$ of protons $(\mathrm{c}, \mathrm{d}, \mathrm{e}, \mathrm{f})$ are also observed. Fig. 8 exhibits ${ }^{13} \mathrm{C}$ NMR bands at $166.95\left(\mathrm{C}_{\mathrm{CONH}}\right), 157.70\left(\mathrm{C}_{14}\right), 156.37\left(\mathrm{C}_{4}\right), 150.45\left(\mathrm{C}_{5}\right), 148.63$ $\left(\mathrm{C}_{13}\right), 44.03\left(\mathrm{C}_{9}\right), 42.61\left(\mathrm{C}_{8}\right), 131.08\left(\mathrm{C}_{11}\right), 130.25\left(\mathrm{C}_{7}\right), 128.77$ $\left(\mathrm{C}_{2}\right), 124.57\left(\mathrm{C}_{1}\right), 123.88\left(\mathrm{C}_{12}\right), 121.76\left(\mathrm{C}_{10}\right), 120.00\left(\mathrm{C}_{3}\right)$, $119.12\left(\mathrm{C}_{6}\right)$.

The monomer (Ma) reacts with 1,5-diaminonaphthalene to form polyamide with more solubility in the polar solvent. This polymer is characterized by FTIR, ${ }^{1} \mathrm{H}$ and ${ }^{13} \mathrm{C}$ NMR as shown in Figs. 9-11.
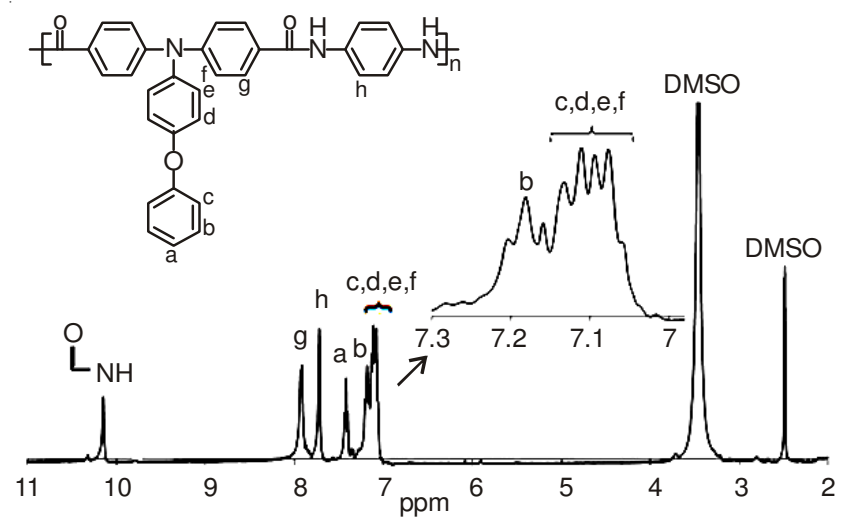

Fig. 7. ${ }^{1} \mathrm{H}$ NMR of compound poly (amine-amide) (pa1)

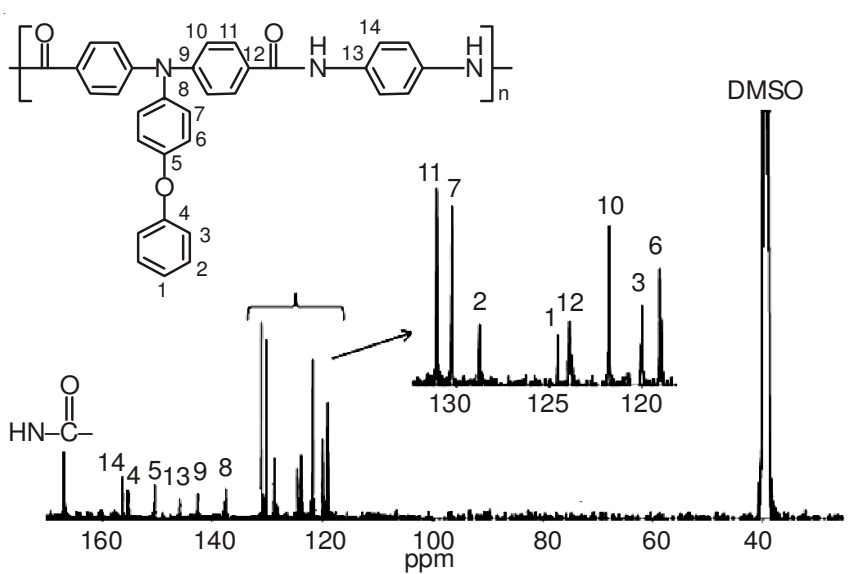

Fig. $8 .{ }^{13} \mathrm{C}$ NMR of poly (amine-amide) (Pa1) in DMSO- $d_{6}$

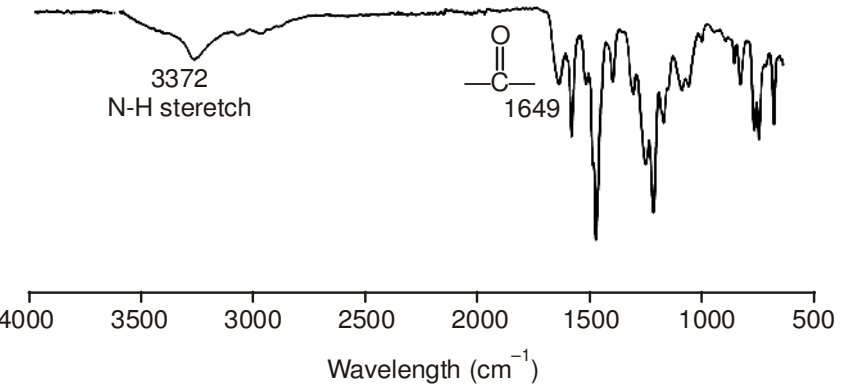

Fig. 9. FTIR spectrum of poly (amine-amide) (pa2)

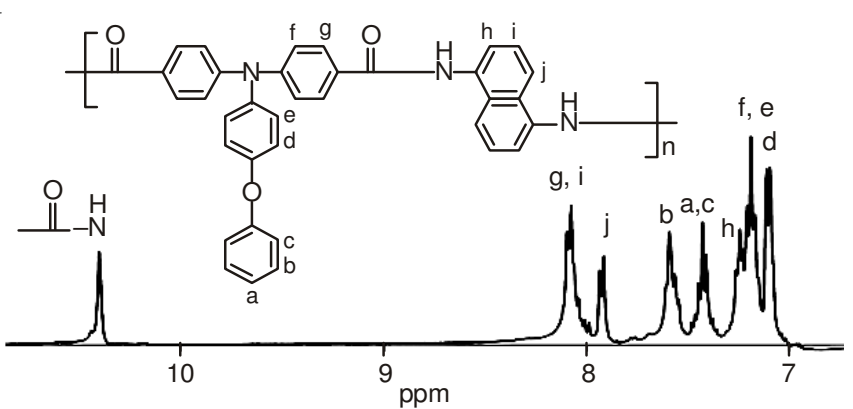

Fig. 10. ${ }^{1} \mathrm{H}$ NMR of compound poly (amine-amide) (pa2)
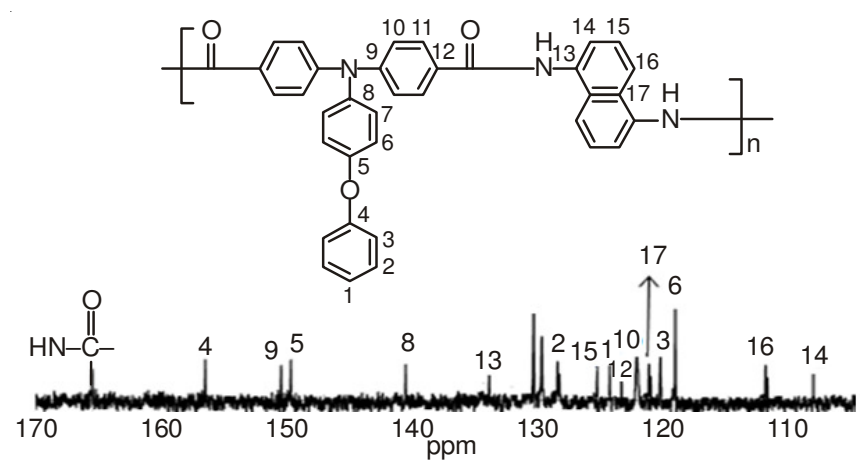

Fig. $11 .{ }^{13} \mathrm{C}$ NMR of poly (amine-amide) $(\mathbf{P a} 2)$

\section{Polymer properties}

Solubility: The qualitative solubility properties of poly(amine-amide)s in several organic solvents at $10 \%(\mathrm{w} / \mathrm{v})$ are also summarized in Table-1. All the polymers exhibited excellent solubility in polar organic solvents such as NMP and DMAc. The enhanced solubility can be attributed to the presence of introduced triphenylamine unit. Polymers (pa2), (pb2), (pc2) have more solubility than others because the more bulky pendent naphthalene group chromophores in the repeating unit leading to increase in free volume in the polymer

\begin{tabular}{|c|c|c|c|c|c|c|c|c|}
\hline \multirow{3}{*}{$\begin{array}{c}\text { Polymer } \\
\text { code }\end{array}$} & \multicolumn{7}{|c|}{$\begin{array}{c}\text { TABLE-1 } \\
\text { INHERENT VISCOSITY }\left(\eta_{\text {inh }}\right) \text { AND SOLUBILITY OF AROMATIC POLYAMIDES }\end{array}$} & \\
\hline & \multirow{2}{*}{$\eta_{\text {inh }}^{b}(d L / g)$} & \multicolumn{7}{|c|}{ Solvent $^{\mathrm{a}}$} \\
\hline & & NMP & DMAc & DMF & DMSO & $m$-Cresol & THF & $\mathrm{CHCl}_{3}$ \\
\hline (pa1) & 0.42 & ++ & ++ & ++ & ++ & - & - & - \\
\hline$(\mathbf{p b l})$ & 0.46 & ++ & ++ & ++ & ++ & - & - & - \\
\hline (pc1) & 0.43 & ++ & ++ & ++ & ++ & - & - & - \\
\hline (pa2) & 0.65 & ++ & ++ & ++ & ++ & - & - & - \\
\hline (pb2) & 0.60 & ++ & ++ & ++ & ++ & - & - & - \\
\hline (pc2) & 0.71 & ++ & ++ & ++ & ++ & - & - & - \\
\hline
\end{tabular}

${ }^{a}$ Solubility: ++: soluble at room temperature, + : soluble on heating, -: insoluble even on heating. ${ }^{b}$ Measured at a polymer concentration of $0.5 \mathrm{~g} / \mathrm{dL}$ in DMAc at $30^{\circ} \mathrm{C}$ 
chains to allow more solvent to come in. Furthermore, polymers (pb2)- (pc2) are more flexibility. The excellent solubility makes these polymers convenient to process into articles by spin-coating.

Thermal properties: Thermal behavior of all the poly(amine-amide)s are summarized in Table-2. They showed high glass transition temperatures $\mathrm{T}_{\mathrm{g}}$ in the range of (292.62246.28) ${ }^{\circ} \mathrm{C}$. The $\mathrm{T}_{\mathrm{g}}$ values of these poly(amine-amide)s generally decreased with decreasing stiffness of the diamine component. So polymers with phenylenediamine exhibited high $\mathrm{T}_{\mathrm{g}}$ value due to more rigidity than of polymers with $1,5-$ diamine. The lowest $\mathrm{T}_{\mathrm{g}}$ value of poly(amine-amide)s(pa2) can be explained in terms of the flexibility and low rotation barrier of its diamine moiety. Poly(amine-amide)(pc1) exhibited the highest $\mathrm{T}_{\mathrm{g}}$ value $\left(292.62{ }^{\circ} \mathrm{C}\right)$ in this series polymers because of the presence of rigid phenylenediamine and cross-linking behavior due to presence of four carboxyl groups in its monomer as shown in Fig. 12.

TABLE-2

THERMAL PROPERTIES OF POLY(AMINE-AMIDE)S

\begin{tabular}{|c|c|c|c|c|c|}
\hline $\begin{array}{c}\text { Polymer } \\
\text { code }\end{array}$ & $\begin{array}{c}\text { Onset }^{2} \\
\left({ }^{\circ} \mathrm{C}\right)\end{array}$ & $\begin{array}{l}\mathrm{T}_{\mathrm{g}}^{\mathrm{b}} \\
\left({ }^{\circ} \mathrm{C}\right)\end{array}$ & $\begin{array}{c}\mathrm{T}_{\mathrm{d}} 5 \% \text { wt. } \\
\left({ }^{\circ} \mathrm{C}\right)\end{array}$ & $\begin{array}{l}\mathrm{T}_{\mathrm{d}} 10 \% \\
\text { wt. }\left({ }^{\circ} \mathrm{C}\right)\end{array}$ & $\begin{array}{c}\text { Char. }^{\circ} \\
(\%)\end{array}$ \\
\hline pa1 & 254.89 & 270.85 & 428.26 & 532.11 & 65 \\
\hline pb1 & 256.74 & 280.79 & 482.34 & 541.34 & 65 \\
\hline pc1 & 266.61 & 292.62 & 531.21 & 578.42 & 67 \\
\hline pa2 & 241.77 & 246.28 & 478.54 & 537.20 & 63 \\
\hline pb2 & 254.36 & 268.72 & 469.13 & 535.21 & 63 \\
\hline pc2 & 253.95 & 276.20 & 510.57 & 551.23 & 65 \\
\hline \multicolumn{6}{|c|}{$\begin{array}{l}\text { a: onset temp. recorded by DSC. } \\
\text { b: the midpoint temperature of base line shift on the subsequent DSC } \\
\text { trace (from } 30 \text { to } 350{ }^{\circ} \mathrm{C} \text { at heating rate } 20^{\circ} \mathrm{C} / \mathrm{min} \text { ) was defined as } \mathrm{T}_{\mathrm{g}} \text {. } \\
\mathrm{T}_{\mathrm{d}} \text { : Decomposition temperature at which a } 5 \% \text { or } 10 \% \text { weight loss was } \\
\text { recorded by TGA at a heating rate of } 20^{\circ} \mathrm{C} / \mathrm{min} \text {. } \\
\text { e: Residual weight percentage at } 800^{\circ} \mathrm{C} \text { under nitrogen flow }\end{array}$} \\
\hline
\end{tabular}

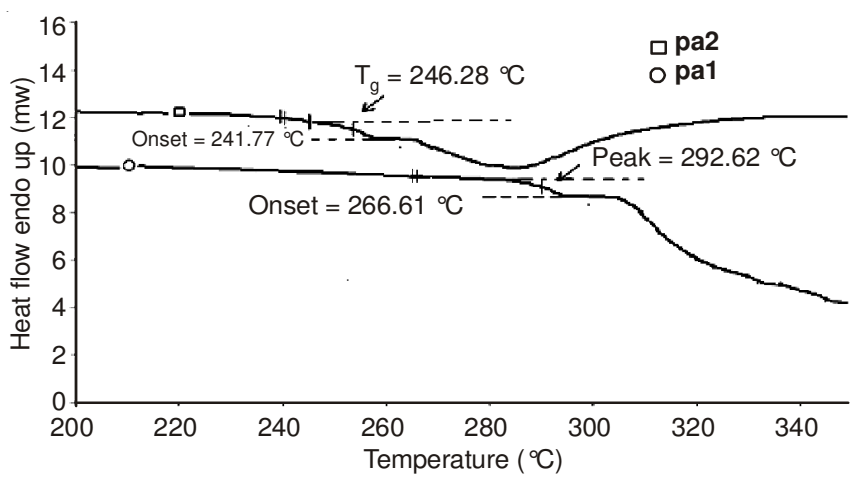

Fig.12. DSC of poly(amine-amide)s (pa1), (pc1)

Fig. 13 shows the TGA curves of poly(amine-amide) (pa1). The decomposition temperatures $\left(\mathrm{T}_{\mathrm{d}}\right)$ at 5 and $10 \%$ weight losses in nitrogen atmosphere are given in Table-2. All the poly(amine-amide)s exhibited good thermal stability with insignificant weight loss up to $400{ }^{\circ} \mathrm{C}$ in nitrogen. The $5 \%$ weight-loss temperatures in nitrogen were recorded in the range of (428.26-510.67) ${ }^{\circ} \mathrm{C}$ and (532.11-551.23) ${ }^{\circ} \mathrm{C}$ for $10 \%$ weight. Due to their high aromatic content, these polymers revealed high char yields in nitrogen, more than $60 \%$ at $800{ }^{\circ} \mathrm{C}$.

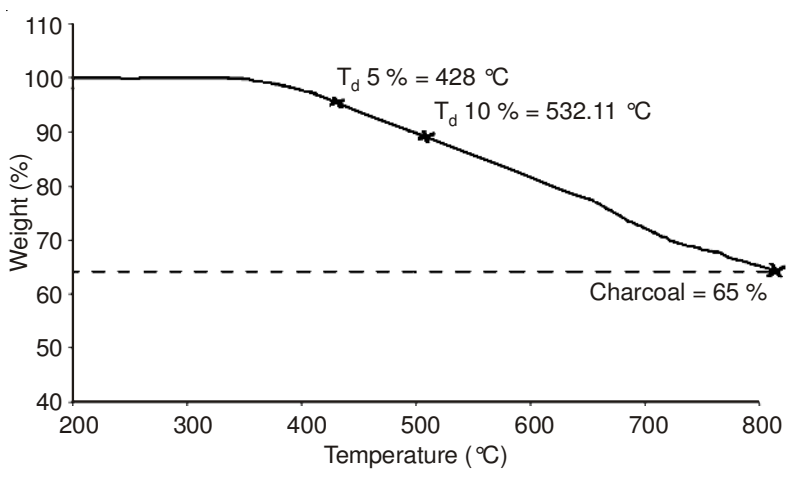

Fig. 13. TGA of poly(amino-amide) (pa1)

Spectral properties: The optical properties of poly-(amineamide)s were investigated by UV-Visible and photoluminescence spectroscopy (PL). The results are summarized in Table-3. The dilute solution of these poly(amine-amide)s in NMP exhibited strong UV-visible absorption bands at (313-363) nm, assignable to the $\left(n-\pi^{*}\right)$ transition resulting from the conjugation between the aromatic rings and nitrogen atoms and transition from the characteristic $\left(\pi-\pi^{*}\right)$ transitions of naphthalene chromophore ${ }^{30}$. Their spectra in NMP solution showed photoluminescence emission maxima bands around (423-488) $\mathrm{nm}$ in the blue region. Fig. 14 and 15 show the UV-visible absorption and photoluminescence spectra for all prepared poly(amine-amide)s. Fig. 16 showed the strong fluorescence emissions in the blue region which can be explained from the decreased intra- and intermolecular electronic interactions. The bulky, crank effective in decreasing charge transfer formation within or between polymer chains through steric hindrance. The UV-visible transmittance spectra of these poly(amine-amide)s films and cutoff wavelengths (absorption edge $\left.\lambda_{\circ}\right)$ in the range of (410-448) nm are also shown in Fig. 16.

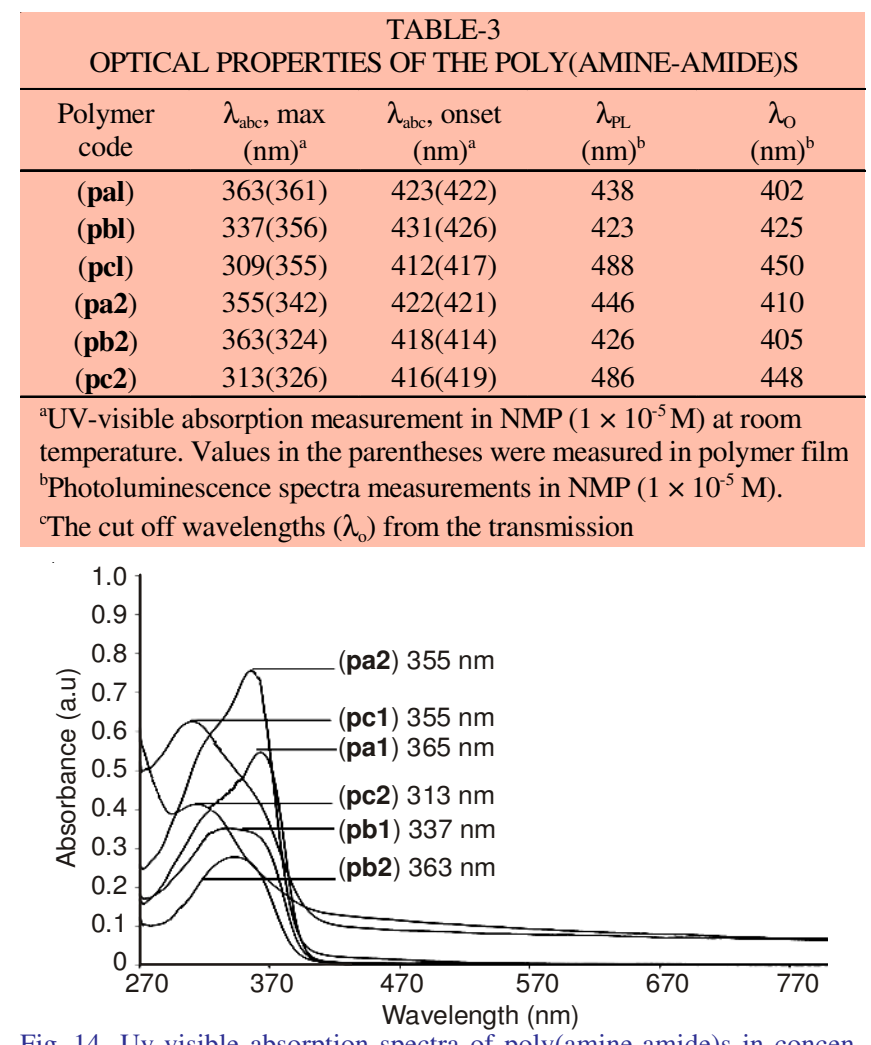

Fig. 14. Uv-visible absorption spectra of poly(amine-amide)s in concentration (10-5 M) in NMP 


\begin{tabular}{cccccc}
\hline Polymer & $\mathrm{E}_{\text {onse }} / \mathrm{V}(v s . \mathrm{Ag} / \mathrm{AgCl})$ & $1_{\text {abc }}$ onset & $\mathrm{HOMO}^{\mathrm{a}}$ & LUMO $^{\mathrm{b}}$ & \multicolumn{2}{c}{$\mathrm{HOMO}-\mathrm{LUMO}^{\mathrm{c}}$} \\
\hline Code & in $\mathrm{CH}_{3} \mathrm{CN}$ & $(\mathrm{nm})$ & $(\mathrm{eV})$ & 2.77 & $\mathrm{gap}^{\mathrm{c}}(\mathrm{eV})$ \\
\hline$(\mathbf{p a l})$ & 1.35 & $423(422)$ & 5.71 & 2.81 & 2.94 \\
$(\mathbf{p b l})$ & 1.33 & $431(426)$ & 5.72 & 2.74 & 2.91 \\
$(\mathbf{p c l})$ & 1.32 & $412(417)$ & 5.71 & 2.83 & 2.97 \\
$(\mathbf{p a 2})$ & 1.38 & $416(419)$ & 5.77 & 2.76 & 2.94 \\
$(\mathbf{p b 2})$ & 1.36 & $418(414)$ & 5.75 & 2.76 \\
$(\mathbf{p c 2})$ & 1.32 & $422(421)$ & 5.71 & 2.95 \\
\hline
\end{tabular}

a; HOMO energy levels were calculated from cyclic voltammetry and were and were referenced to ferrocene $(4.8 \mathrm{eV})$

b: LUMO = HOMO-gap

c: Energy gap data were calculated of thin film by the equation: Energy gap $=1240 \lambda$ onset of polymer film

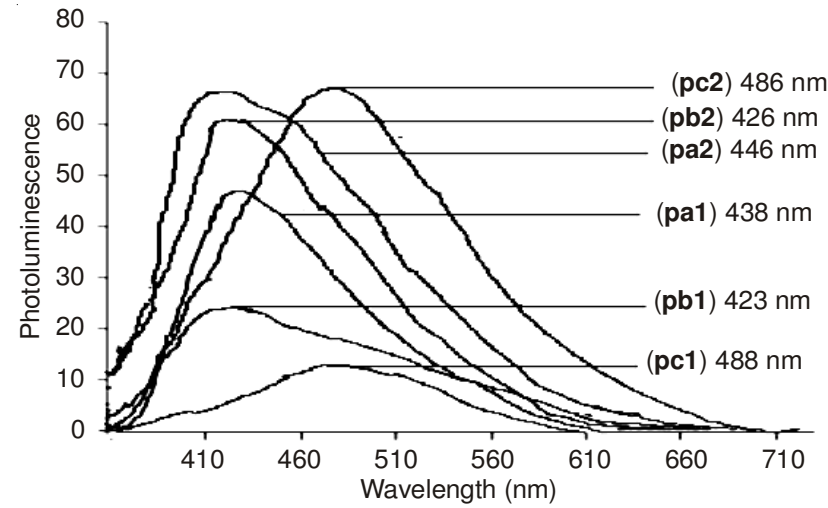

Fig. 15. UV-visible photoluminescence emission of poly(amine-amide)s in concentration $\left(10^{-5} \mathrm{M}\right)$ in NMP

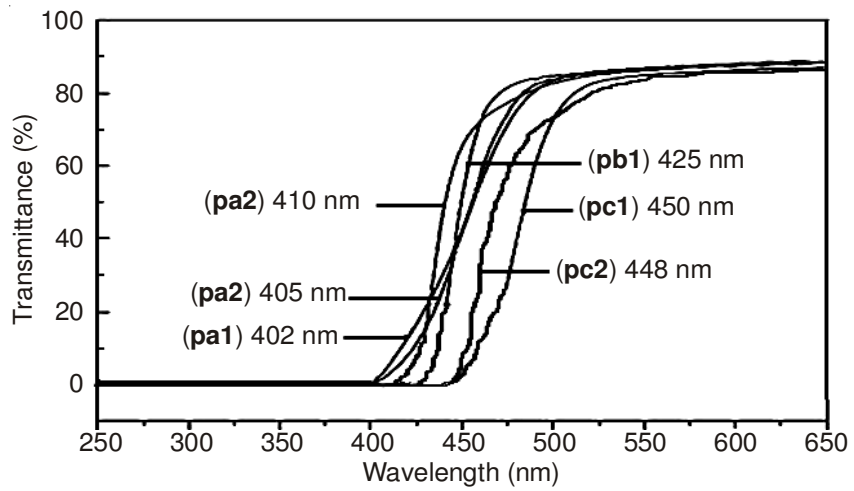

Fig. 16. UV-visible transmittance spectra of poly(amine-amide)s with a concentration $\left(10^{-5} \mathrm{M}\right)$ in NMP

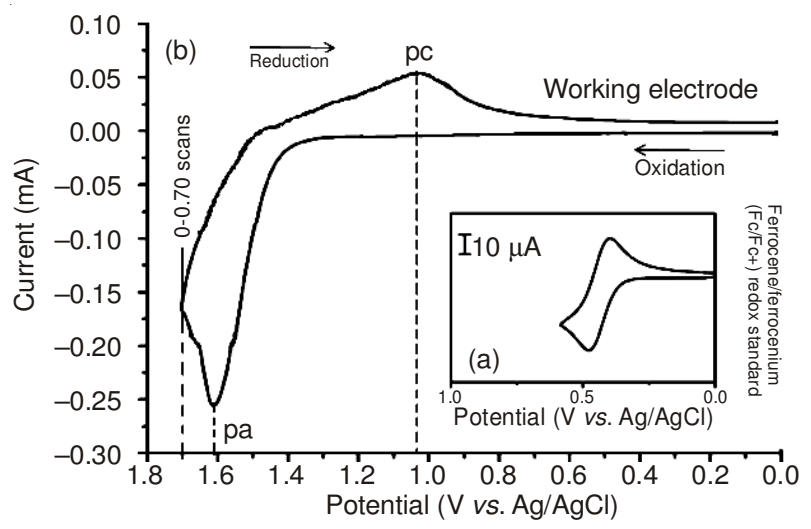

Fig. 17. Cyclic Voltammograms of (a) ferrocene as reference and (b) the cast film of poly(amine-amide) (pa1) on the indium-tin oxide (ITO)coated glass substrate in $\mathrm{CH}_{3} \mathrm{CN}$ containg $0.1 \mathrm{M}$ TBAP, with a scan rate of $0.1 \mathrm{~V} / \mathrm{s}$
Electrochemical properties: The redox behavior for poly (amine-amide)s was investigated by cyclic voltammetry for the cast film on an indium tin oxide-coated glass substrate as working electrode in dry acetonitrile containing $0.1 \mathrm{M}$ of tetrabutylammonium perchlorate as an electrolyte, under nitrogen atmosphere. All the poly (amine-amide)s showed a reversible oxidation process. Fig. 17 shows the typical cyclic voltammogram for poly(amine-amide) (pa1) recorded at scanning rate of $0.1 \mathrm{~V} / \mathrm{s}$. One reversible oxidation redox couple with halfwave at $\mathrm{E}_{1 / 2}=1.32 \mathrm{~V}(v s . \mathrm{Ag} / \mathrm{AgCl})$ in the oxidative scan was observed. Because of electrochemical stability of the films and good adhesion between the polymer and indium tin oxide substrate, the polyamide $\mathbf{4 a}$ exhibited good reversibility of electrochromic characteristics by continuous five scans between $0.0-1.70 \mathrm{~V}$ changing colour from original pale yellowish to blue. The energy of the HOMO and LUMO levels of the corresponding poly(amine-amide)s can be determined from the oxidation onset $\left(\mathrm{E}_{\text {onset }}\right)$ and the onset absorption wavelength of the UV-Visible absorption of thin films $\mathrm{s}^{30}$ and the results are listed in Table-4. The external ferrocene/ferrocenium $(\mathrm{Fc} / \mathrm{Fc}+)$ redox standard $\mathrm{E}_{\text {onset }}$ is $0.41 \mathrm{~V}$ vs. $\mathrm{Ag} / \mathrm{AgCl}$ in $\mathrm{CH}_{3} \mathrm{CN}$ and the HOMO energy for the $\mathrm{Fc} / \mathrm{Fc}+$ standard is $4.80 \mathrm{eV}$ with respect to the zero vacuum level. Therefore, the HOMO energy for 4a has been evaluated to be $5.71 \mathrm{EV}$ as follows:

$\mathrm{E}_{1 / 2}$ (onset $)=\left(\mathrm{E}_{\mathrm{PC}}+\mathrm{E}_{\mathrm{pa}}\right) / 2$ where $\mathrm{E}_{\mathrm{pc}}$ and $\mathrm{E}_{\mathrm{pa}}$ are potentials of cathode and anode respectively

$$
\begin{aligned}
& \left.\mathrm{E}_{1 / 2} \text { (onset }\right)=(1.04+1.602) / 2=1.32 \mathrm{~V} \\
& \mathrm{E}_{\text {Hомо }}=\left[\mathrm{E}_{1 / 2}(\text { onset })-\mathrm{E}_{1 / 2}(\text { ref. })+4.8\right] \mathrm{eV} \\
& \mathrm{E}_{\text {Hомо }}=[1.32-0.41+4.8]=5.71 \mathrm{eV} \\
& \mathrm{Gap}=1240 / \lambda_{\text {onset }}=1240 / 422=2.94 \mathrm{eV} \\
& \mathrm{HOMO}-\mathrm{LUMO}=\mathrm{GAP} \\
& \mathrm{LUMO}=5.71-2.94=2.77 \mathrm{eV}
\end{aligned}
$$

\section{REFERENCES}

1. N.C. Greenham, S.C. Moratti, D.D.C. Bradley, R.H. Friend and A.B. Holmes, Nature, 365, 628 (1993).

2. Y. Shirota, J. Mater. Chem., 10, 1 (2000).

3. C.W. Tang and S.A. Vanslyke, Appl. Phys. Lett., 51, 913 (1987).

4. C.W. Tang, S.A. Vanslyke and C.H. Chen, J. Appl. Phys., 65, 3610 (1989).

5. C. Adachi, K. Nagai and N. Tamoto, Appl. Phys. Lett., 66, 2679 (1995).

6. Y.-F. Ke, D.-S. Tsai and Y.S. Huang, J. Mater. Chem., 15, 2122 (2005).

7. A.P. Kulkarni, C.J. Tonzola, A. Babel and S.A. Jenekhe, J. Mater. Chem., 16, 4556 (2004).

8. M. Thelakkat, J. Hagen, D. Haarer and H.W. Schmidt, Synth. Met., 102, 1125 (1999).

9. S.H. Cheng, S.-H. Hsiao, T.-H. Su and G.-S. Liou, Macromolecules, 38, 307 (2005). 
10. U. Mitschke and P. Bäuerle, J. Mater. Chem., 10, 1471 (2000).

11. E. Ueta, H. Nakano and Y. Shirota, Chem. Lett., 12, 2397 (1994).

12. H.H.Yang, Aromatic High-Strength Fibers, John Wiley \& Sons, New York/Chichester/Brisbane/Toronto/Singapore (1989); ISBN 0-47162988-X.

13. Y. Imai, High Perform. Polym., 7, 337 (1995).

14. Y. Imai, React. Funct. Polym., 30, 3 (1996).

15. G.S. Liou and S.H. Hsiao, J. Polym. Sci. A Polym. Chem., 40, 1781 (2002).

16. S.H. Hsiao, G.S. Liou and C.W. Chen, J. Polym. Sci. A Polym. Chem., 42, 3302 (2004).

17. G.S. Liou, S.H. Hsiao, M. Ishida, M. Kakimoto and Y. Imai, J. Polym. Sci. A Polym. Chem., 40, 2810 (2002).

18. S.H. Hsiao and G.S. Liou, J. Polym. Sci. A Polym. Chem., 41, 94 (2003),

19. K. Choi, S.J. Yoo, Y.-E. Sung and R. Zentel, Chem. Mater., 18, 5823 (2006).

20. K. Ogino, A. Kanegae, R. Yamaguchi, H. Sato and J. Kurjata, Macromol. Rapid Commun., 20, 103 (1999).
21. M.Y. Chou, M.- Leung, Y.O. Su, C.L. Chiang, C.-C. Lin, J.-H. Liu, C.K. Kuo and C.-Y. Mou, Chem. Mater., 16, 654 (2004).

22. S.-H. Cheng, S.-H. Hsiao, T.-H. Su and G.-S. Liou, Macromol., 38, 307 (2005).

23. S.-H. Hsiao, Y.-M. Chang, H.-W. Chen and G.-S. Liou, J. Polym. Sci. A Polym. Chem., 44, 4579 (2006)

24. S. Beaupré, J. Dumas and M. Leclerc, Chem. Mater., 18, 4011 (2006).

25. K. Choi, S.J. Yoo, Y.-E. Sung and R. Zentel, Chem. Mater., 18, 5823 (2006).

26. N. Yamazaki, F. Higashi and J. Kawabata, J. Polym Sci: Polym Chem., 12, 2149 (1974).

27. M. Strukelj, F. Papadimitrakopoulos, T.M. Miller and L.J. Rothberg, Science, 267, 1969 (1995).

28. G.S. Liou, N.K. Huang and Y.L. Yang, J. Polym. Sci. A Polym. Chem., 44, 4095 (2006).

29. Y. Oishi, K. Mori, H. Hirahara, Y. Fujimura and K. Miya, Japanese Patent, 11-255,723 (1999).

30. D.M. de Leeuw, M.M.J. Simenon, A.R. Brown and R.E.F. Einerhand, Synth. Met., 87, 53 (1997). 